\title{
Effects of Tender Coconut Water on Antioxidant Enzymatic Superoxida Dismutase (SOD), CATALASE (CAT), Glutathione Peroxidase (GPx) and Lipid Peroxidation In Mercury Exposure Workers
}

\author{
Siti Thomas Zulaikhah ${ }^{1}$, Anies $^{2}$, Ari Suwondo ${ }^{3}$, Santosa $^{4}$ \\ ${ }^{1}$ Department of Public Health Sciences Faculty of Medicine, Sultan Agung Islamic University (UNISSULA ) Semarang, Central Java, \\ Indonesia
}

${ }^{2}$ Department of Public Health Sciences Faculty of Medicine, Diponegoro University Semarang, Central Java, Indonesia

${ }^{3}$ Faculty of Public Health , University of Diponegoro Diponegoro University Semarang, Central Java, Indonesia

${ }^{4}$ Faculty of Medicine, State University of March Surakarta ( UNS ) Central Java, Indonesia

\begin{abstract}
Background: The traditional gold miners use mercury to process gold. Continuous exposure to mercury will trigger the formation of Reactive Oxygen Species (ROS), increase lipid peroxidation, cause oxidative stress on cells or tissues, inhibit the enzyme, cause cell damage, damage to the structure of proteins, DNA damage, interfere with the body's antioxidant metabolism particularly superoxide dismutase (SOD) and glutathione peroxidase (GPx). This study was intended to prove that the administration of tender coconut water $450 \mathrm{~mL} /$ day for 30 days can increase the antioxidant enzymatic and decrease lipid peroxidation. Methods: Randomized Pre and Postest Control Group Design, a total of 76 gold mining workers were randomly selected divided into two groups of 38 each. The treatment group was given $450 \mathrm{ml}$ of coconut water and the control one was given $450 \mathrm{~mL}$ of plain water for 30 days. The Blood test was conducted to evaluate of antioxidants including SOD, CAT, GPX and MDA as indicators of lipid peroxidation by Elisa method. Mann Whitney test was applied for data analysis. Results: The mean level of SOD, CAT, GPX in the treatment group was higher than the that of control, while MDA was lower (SOD $337 \pm 52.5$ vs $267 \pm 35.2 \mathrm{U} / \mathrm{mL}$ ), CAT (2.0 \pm 0.5 vs $1.9 \pm 0.4 \mathrm{U} / \mathrm{mL}), \mathrm{GPx}(79.9 \pm 12.3$ vs $68.8 \pm 14.7 \mathrm{U} / \mathrm{mL}), M D A(3.6 \pm 0.4 \mathrm{vs} 4.5 \pm 0.5 \mathrm{nmol} / \mathrm{mL})$. The mean delta SOD, CAT, GPx of treatment group was larger than that of control, while MDA was smaller (SOD $75.4 \pm 27.5$ vs. $-1.7 \pm 8.2$ ), CAT (0.23 \pm 0.28 vs $-0,04 \pm 0.25)$, GPx (10.40 $\pm 11.8 v s-1.55 \pm$ 3.8), MDA (-0.95 \pm 0.26 vs $0.1 \pm 0.5)$. Conclusion: the administration of tender coconut water $450 \mathrm{ml} / \mathrm{day}$ for 30 days can increase antioxidant SOD, CAT, GPx and decrease lipid peroxidation in subjects exposed to mercury.
\end{abstract}

Keywords: Mercury, ROS, SOD, CAT, GPx, MDA, tender coconut water

\section{Introduction}

Mercury ( $\mathrm{Hg})$ is highly toxic metal. A continuous exposure to mercury will trigger the formation of Reactive Oxygen Species (ROS), increase lipid peroxidation, cause oxidative stress dismutase (SOD) and glutathione peroxidase (GPx). $\underline{\mathbf{1}}^{-}$ $\underline{3}$. The largest global sources of mercury emissions are from the traditional gold mining. In Indonesia, Approximately $57.5 \%$ of the source of mercury emissions is from traditional gold minings with a total emission of about 195 tons/year. In 2010 there were approximately 900 gold mining sites employing about 250,000 workers. ${ }^{4}$. In Wonogiri Regency, Central Java, in the area around the mountain Randukuning, there is a number of traditional gold mining activities using amalgamation method with mercury as a medium to bind gold.Gold miners are greatly at risk to get mercury poisoning because they may be continuously exposed. The high risk of exposure to mercury in the traditional gold processing occurs during the screening process and thermal annealing. Gold miners may be exposed to mercury vapor through inhalation because of the gold ore that had been bound by the mercury will be heated at a very high temperature. $80 \%$ of inhaled mercury vapor will be absorbed into the lung penetrating the blood brain barrier and placenta and distributed throughout the body. ${ }^{6}, 7$

The study conducted by the Engineering Center for Environmental Health (BTKL) Yogyakarta among 8 gold mine workers in the Jendi village Selogiri Wonogiri District in August 2009 showed that $100 \%$ of workers had a high level of mercury poisoning with $70-257 \mathrm{mg} / \mathrm{L}$ blood mercury level. The finding of the preliminary research showed that mean mercury level among gold miners was $104.49 \mu \mathrm{g} / \mathrm{L}$, exceeding WHO's reccomended therehold $(\geq 10 \mu \mathrm{g} / \mathrm{L})$. This high mercury level may increase levels MDA, lower antioxidants SOD level and GPx in workers exposed to harmful impacts merkury. $\underline{\mathbf{8}}$ The dangerous impact when mercury accumulates in the body is releasing ROS and increasing lipid peroxidation in the body. ${ }^{2}$ The emergence of ROS is caused by low antioxidant system, which is due to the reduction of thiol group on the antioxidant enzyme protein resulted from being bound by mercury, because these compounds have a strong affinity for thiol groups. Such conditions lead to a decrease in the 


\section{International Journal of Science and Research (IJSR) \\ ISSN (Online): 2319-7064 \\ Index Copernicus Value (2013): 6.14 | Impact Factor (2014): 5.611}

activity of antioxidant enzymes such as glutathione peroxidase (GPx), superoxide dismutase (SOD) and catalase (CAT), resulting in the depletion of the levels of reduced glutathione (GSH) and accumulation of $\mathrm{H}_{2} \mathrm{O}_{2}$, which in turn causes oxidative stress. $\underline{\mathbf{1 0}}, \underline{\mathbf{1 1}}$ The elimination of ROS is essential for maintaining the integrity of cell function and can be done by increasing the antioxidant activity. $\underline{\mathbf{1 2}}$ Natural antioxidants can be an alternative to be potentially developed as the synthetic antioxidants are likely to have side effects which are not yet discovered. Natural antioxidants are able to protect the body from cell damage induced by ROS, able to inhibit the degenerative disease and is capable of preventing lipid peroxidation . $\underline{\mathbf{2}}$ Food containing naturally occuring antioxidants can be used as a strategy to reduce morbidity and mortality, especially caused by stress oxidative $\underline{\mathbf{1 3}}$ and can reduce the high prevalence of degenerative diseases. $\underline{\mathbf{1 4}}$

Tender coconut water is natural drink, healthy, nutritious , provided by nature and is widely available in tropical countrie. Indonesia is a country with the largest cococut field in the world.. $\mathbf{5}$ Tender coconut water has therapeutic effects, containing various nutrients such as minerals, vitamins, antioxidants, amino acids, enzymes. $\underline{\mathbf{1 6}}$ Recent studies suggest that tender coconut water is rich in free amino acid ,source L- arginine and vitamin $\mathrm{C}$, which can prevent heart diseases and peroxidation. ${ }^{16,}{ }^{17}$ The study findings demonstrate that tender coconut water consumption can reduce oxidative stress and increase antioxidant status indicated by reduced MDA level, increased antioxidant enzymes such as SOD , CAT and GPX in mice. $\underline{\mathbf{1 6}}, \underline{\mathbf{1 8}}$ Thus the present study was conducted to investigate the effects of tender coconut water on antioxidant status and lipid peroxidation in mercury exposure workers.

\section{Methods}

The design applied in this study was true experimental design with Randomized pre and post test control group design. $\underline{19}$ The population of this study was all traditional gold mining workers exposed to mercury for more than 5 years in Selogiri Wonogiri, while the samples were the population who met the inclusion and exclusion criteria. Inclusion criteria for male, 20-60 years of age with employment duration $\geq 5$ years, normal nutritional status (BMI) and willing to become respondents, while exclusion criteria were subjects having a history of heart disease, liver disease, lung disease, kidney disease, diabetes, and other severe diseases. Minimum sample quantity was determined based on the formula of the samples for analytical research of numerical unpaired data. $\underline{\mathbf{2 0}}, \underline{\mathbf{2 1}}$ Minimum total sample total was 35 and to avoid drop-out during the intervention, the sample was added $10 \%$. This Research was conducted on two groups of 38 subjects each so the the total sample was 76 workers using simple random sampling.. Subjects who met the inclusion criteria were randomly allocated into treatment group and the control group. The treatment group was given tender coconut water $450 \mathrm{~mL} /$ day for 30 days, and the control group was given $450 \mathrm{~mL}$ of plain water/day for 30 days. Either subjects or the researchers did not know into which group the subject was allocated (double blind). The Confounding variables were controlled with restriction and randomization so that the distribution of subject characteristics as well as confounding variables in the control group and the treatment group were equal or balanced. Data were obtained through interviews, recall 24 hours $\times 3$ days, checking the nutritional status and health status, and laboratory examination of blood samples. Collective Data were analyzed using SPSS 16 for windows, the significance level $(\alpha)$ which was used to test the hypothesis was 5\%. The first test performed was the normality test of data because the data scale was ratio. Mann Whitney test was used for data analysis because data distribution of SOD, CAT, GPx, MDA in both groups was not normal $(\mathrm{p}<0.05)$.

\section{Ethics approval}

This study has obtained permission (ethical clearance) from the Health Research Ethics Committee (IEC) Diponegoro University School of Medicine and Hospital, Dr. Kariadi with (registration number 481 / EC / FK-RSDK / 2014).

\section{Results}

The subjects of 76 workers were divided into two groups via randomized blocks, resulting in 38 people of the control group, and 38 people of the treatment group. In order to ensure that the characteristics of the subjects in the treatment group and the control one before treated were equally distributed, it was necessary to be analyzed by different test in both groups.

The mean levels of mercury for the control group was $62.7 \pm$ $45.9 \mathrm{pg} / \mathrm{L}$ with minimum levels of $10.12 \mathrm{mg} / \mathrm{L}$ and a maximum level of $187.25 \mathrm{mg} / \mathrm{L}$, while that of the treatment group was $56.9 \pm 46.6 \mathrm{mg} / \mathrm{L}$ levels minimum of $10.29 \mathrm{~g} / \mathrm{L}$ and the maximum level was $190.47 \mu \mathrm{g} / \mathrm{L}$. The analysis resulted in $\mathrm{p}$ value $>0.05$ showing that the mean mercury level in both groups was balanced/ equal.

\section{Chart 1 is Consort of the Study}

Table 1 shows that the characteristics of the subjects in both groups were similar, statistical test implemented were the Man Whitney test for ratio scaled data and Chi-square test for categorical scaled data. The analysis resulted inp value $>$ 0.05 showing that all variables between the treatment group and the control one were homogeneous.

Table 2 shows that the mean levels of SOD after treatment in the treatment group increased as much as $76 \mathrm{U} / \mathrm{mL}$, while in the control group it decreased as much as $2 \mathrm{U} / \mathrm{mL}$ compared to that of before treatment. The mean levels of CAT after treatment in the treatment group had an increase of $0.2 \mathrm{U} / \mathrm{mL}$, while in the control group it remained the same in comparison with before being treated. The mean levels of GPx after treated in the treatment group had an increase of $10.4 \mathrm{U} / \mathrm{mL}$, while in the control group decreased by 1.6 $\mathrm{U} / \mathrm{mL}$ compared to the condition being treated. The mean levels of MDA after being treated in the treatment group decreased by $0.9 \mathrm{nmol} / \mathrm{mL}$ and the control group increased by $0.1 \mathrm{nmol} / \mathrm{mL}$ compared to the condition before treatment.

\section{Volume 4 Issue 12, December 2015}




\section{International Journal of Science and Research (IJSR) \\ ISSN (Online): 2319-7064 \\ Index Copernicus Value (2013): 6.14 | Impact Factor (2014): 5.611}

Table 3 and Graph 1 shows that the mean level of SOD in the control group and the treatment group after treatment increased by $70 \mathrm{U} / \mathrm{mL}(26.2 \%)$, the average in the control group was $267 \mathrm{U} / \mathrm{mL}$, while that of the treatment group was $337 \mathrm{U} / \mathrm{mL}$. The result of the analysis was value $\mathrm{p}=0,000$, which means that giving tender coconut water $450 \mathrm{~mL} /$ day for 30 days increases the levels of SOD in traditional gold miners who are exposed to mercury. The mean levels of CAT in the control group and the treatment group after treatment had an increase of $0.1 \mathrm{U} / \mathrm{mL}$, the mean in the control group was $1.9 \mathrm{U} / \mathrm{mL}$, while the treatment group was $2 \mathrm{U} / \mathrm{mL}$, but it was statistically obtained that value of $\mathrm{p}$ was $=0.109$, which means giving tender coconut water $450 \mathrm{~mL} /$ day for 30 days did not increase the levels of CAT significantly in traditional gold mining workers exposed to mercury. The mean levels of GPx in the control group and the treatment group after treatment had an increase of 11.1 $\mathrm{U} / \mathrm{mL}(16.1 \%)$, the average in the control group was 68.8 $\mathrm{U} / \mathrm{mL}$, while the treatment group was $79.9 \mathrm{U} / \mathrm{mL}$.the analysis resulted in value $p=0.002$, It means that at $\alpha=$ $5 \%$ Ha was accepted, that is, giving tender coconut water $450 \mathrm{~mL} /$ day for 30 days increases the levels of GPx among traditional gold miners who are exposed to mercury. The mean levels of MDA in the control and treatment group after treatment decreased by $0.9 \mathrm{nmol} / \mathrm{mL}(20 \%)$, the mean in the control group was $4.5 \mathrm{nmol} / \mathrm{mL}$, while the treatment group was $3.6 \mathrm{nmol} / \mathrm{mL}$. Result of the analysis obtained was value $\mathrm{p}=0,000$ which means giving tender coconut water $450 \mathrm{~mL}$ / day for 30 days reduces the levels of MDA in the traditional gold miners who are exposed to mercury.

Table 4 and chart 2 shows that the mean delta of SOD in the treatment group increased $(75.4 \pm 27.5 \mathrm{U} / \mathrm{mL})$ and in the control group had a decrease $(-1.7 \pm 8.2 \mathrm{U} / \mathrm{mL})$. The difference in mean delta control and treatment groups was
$73.7 \mathrm{U} / \mathrm{mL}$ the analysis resulted in $\mathrm{p}=0.000$, it means giving tender coconut water $450 \mathrm{~mL} /$ day for 30 days in traditional gold mining workers exposed to mercury causes the average delta levels of SOD was greater when compared to that of control group. The mean level of delta CAT in the treatment group had an increase $(0.23 \pm 0.28 \mathrm{U} / \mathrm{mL})$ and in the control group had a decrease $(-0.04 \pm 0.25 \mathrm{U} / \mathrm{mL})$. The average difference of Delta in the control group and the treatment was $0.19 \mathrm{U} / \mathrm{mL}$. Results of the analysis obtained was the value of $\mathrm{p}$ was $=0,000$, which means that giving tender coconut water $450 \mathrm{~mL} /$ day for 30 days in a traditional gold mining workers exposed to mercury causes an average of delta CAT levels was greater compared to the control group.

The mean delta of GPx levels in the treatment group had an increase $(10.4 \pm 11.8 \mathrm{U} / \mathrm{mL})$ and in the control group had a decrease $(-1.55 \pm 3.8 \mathrm{U} / \mathrm{mL})$. The average difference of Delta in the control group and the treatment was $8.85 \mathrm{U} / \mathrm{mL}$. The analysis resulted obtained in value $p=0.000$, meaning that giving tender coconut water $450 \mathrm{~mL}$ / day for 30 days in traditional gold mining workers exposed to mercury causes the average delta of GPx levels was greater compared to the control group.

The mean delta of MDA levels in the treatment group had a decrease $(-0.95 \pm 0.1 \mathrm{nmol} / \mathrm{mL})$ and in the control group increased $(0.26 \pm 0.5 \mathrm{nmol} / \mathrm{mL})$. The Delta average difference in the control group and the treatment was -0.64 $\mathrm{nmol} / \mathrm{mL}$. Result of the analysis obtained was value $\mathrm{p}=$ 0.000 , which means giving tender coconut water 450 $\mathrm{mL} /$ day for 30 days in traditional gold mining workers exposed to mercury causes the average delta of MDA level was smaller compared to the control group. 
International Journal of Science and Research (IJSR)

ISSN (Online): 2319-7064

Index Copernicus Value (2013): 6.14 | Impact Factor (2014): 5.611

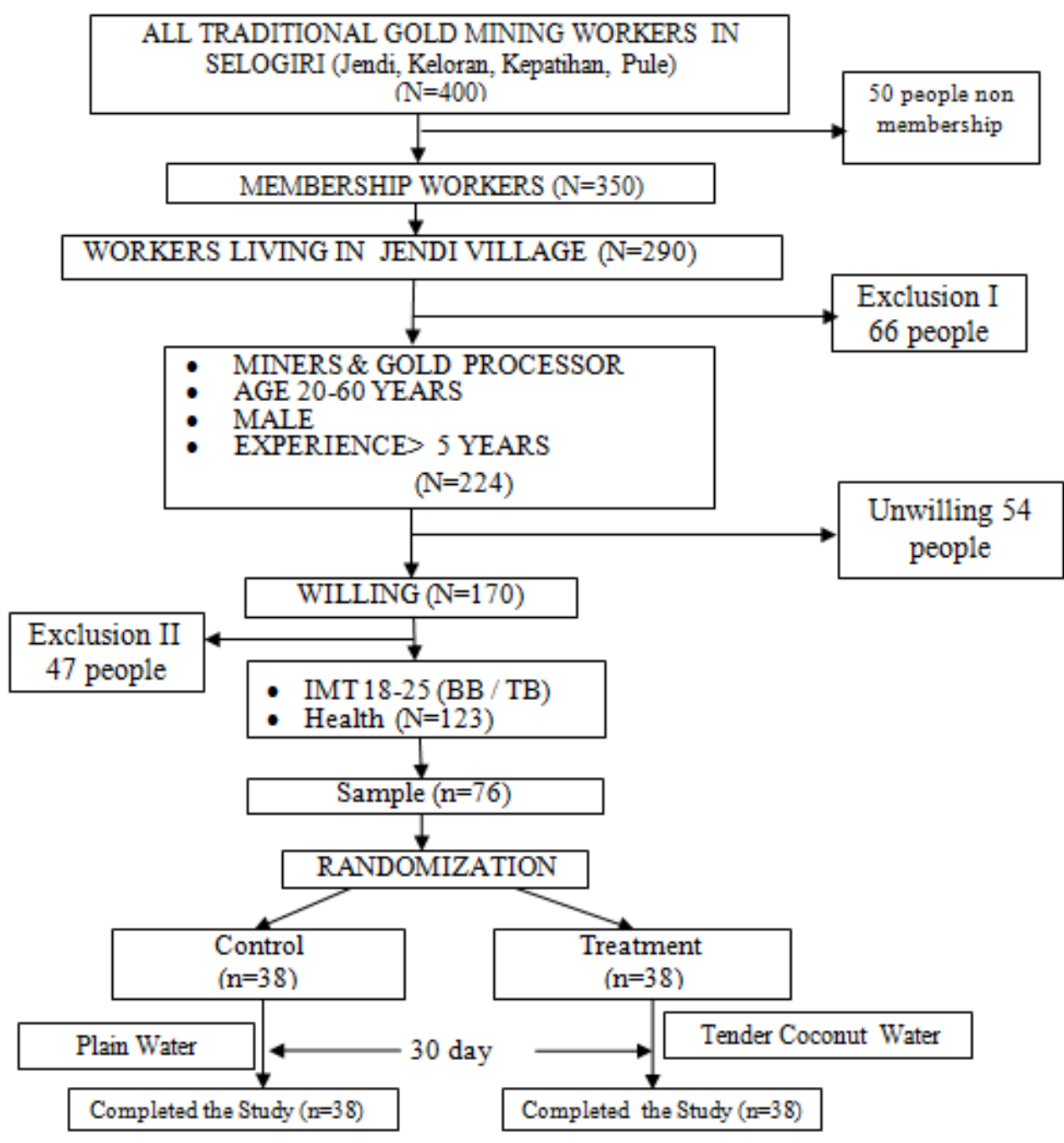

Chart 1. CONSORT

Table 1: Baseline

\begin{tabular}{|c|c|c|c|c|}
\hline No & Characteristics & Treatment & Control & p-value \\
\hline 1. & $\begin{array}{l}\text { Education } \\
\text { - Elementary School } \\
\text { - Junior School } \\
\text { - High School }\end{array}$ & $\begin{array}{l}16(42.1 \%) \\
11(28.9 \%) \\
11(28.9 \%)\end{array}$ & $\begin{array}{l}17(44.7 \%) \\
9(23.7 \%) \\
12(31.6 \%)\end{array}$ & $0.872^{*}$ \\
\hline 2. & $\begin{array}{l}\text { Age (year) } \\
\text { - Mean } \pm \text { SD } \\
\text { - Min - Max (year) }\end{array}$ & $\begin{array}{l}39 \pm 8.5 \\
24-60\end{array}$ & $\begin{array}{c}41.5 \pm 9.9 \\
25-60\end{array}$ & $0.291 *$ \\
\hline 3. & $\begin{array}{l}\text { Experience (year) } \\
\text { - Mean } \pm \text { SD } \\
\text { - Min - Max (year) }\end{array}$ & $\begin{array}{c}13.6 \pm 4.6 \\
6-24\end{array}$ & $\begin{array}{c}13.3 \pm 6,1 \\
5-25\end{array}$ & $0.565^{*}$ \\
\hline 4. & $\begin{array}{l}\text { Total of mercury } \\
\text { consuming } \\
\text { (week/day) } \\
\text { - Mean } \pm \text { SD } \\
\text { - Min - Max } \\
\text { (week/day) }\end{array}$ & $\begin{array}{c}239.5 \pm 71.8 \\
100-400\end{array}$ & $\begin{array}{c}247.5 \pm 79.6 \\
100-400\end{array}$ & $0.712^{*}$ \\
\hline 5. & $\begin{array}{l}\text { Contact period } \\
\text { (hour/day) } \\
\bullet \geq 1 \text { hour / day }\end{array}$ & $38(100 \%)$ & $38(100 \%)$ & ---- \\
\hline 6. & $\begin{array}{l}\text { APD } \\
\text { - Never } \\
\text { - Sometimes }\end{array}$ & $\begin{array}{l}28(73.7 \%) \\
10(26.3 \%)\end{array}$ & $\begin{array}{c}33(86.8 \%) \\
5(13.2)\end{array}$ & $0.249^{*}$ \\
\hline 7. & $\begin{array}{l}\text { Nutrient Status } \\
\text { (IMT) } \\
\text { - Normal }\end{array}$ & $38(100 \%)$ & $38(100 \%)$ & ---- \\
\hline
\end{tabular}

\begin{tabular}{|c|c|c|c|c|}
\hline No & Characteristics & Treatment & Control & p-value \\
\hline 8. & $\begin{array}{l}\text { Health Status } \\
\text { - Sick } \\
\text { - Healthy }\end{array}$ & $\begin{array}{c}0 \\
38(100 \%)\end{array}$ & $\begin{array}{c}3(7.9 \%) \\
35(92.1 \%)\end{array}$ & $0.240^{*}$ \\
\hline 9. & \begin{tabular}{|l|} 
Alcohol \\
- Yes \\
- No \\
\end{tabular} & $\begin{array}{c}1(2.6 \%) \\
37(97.4 \%)\end{array}$ & $\begin{array}{c}1(2.6 \%) \\
37(97.4 \%)\end{array}$ & $1.00^{*}$ \\
\hline 10. & $\begin{array}{l}\text { Drug } \\
- \text { Yes } \\
\text { - No }\end{array}$ & $\begin{array}{c}2(5.3 \%) \\
36(94.7 \%)\end{array}$ & $\begin{array}{c}2(5.3 \%) \\
36(94.7 \%)\end{array}$ & $1.00^{*}$ \\
\hline 11. & $\begin{array}{l}\text { Smoker } \\
\text { - Yes } \\
\text { - No }\end{array}$ & $\begin{array}{c}29(76.3 \%) \\
9(23.7 \%)\end{array}$ & $\begin{array}{l}25(65.8 \%) \\
13(34.2 \%)\end{array}$ & $0.448^{*}$ \\
\hline 12. & $\begin{array}{l}\text { Other Antioxidant } \\
\text { - Yes } \\
\text { - No } \\
\end{array}$ & $\begin{array}{c}4(10.5 \%) \\
34(89.5)\end{array}$ & $\begin{array}{c}4(10.5 \%) \\
34(89.5)\end{array}$ & $1.00^{*}$ \\
\hline 13. & $\begin{array}{l}\text { Vitamin C (mg) } \\
\text { - Mean } \pm \text { SD } \\
\text { - Min - Max }\end{array}$ & $\begin{array}{c}17.75 \pm 0.11 \\
0.0-42.0 \\
\end{array}$ & $\begin{array}{c}15.23 \pm 0.12 \\
0.0-41.8 \\
\end{array}$ & $0.336^{*}$ \\
\hline 14. & $\begin{array}{l}\text { Blood Mercury Level } \\
(\mu \mathrm{g} / \mathrm{L}) \\
\text { - Mean } \pm \mathrm{SD} \\
\text { - Min }- \text { Max }\end{array}$ & $\begin{array}{c}56.9 \pm 46.6 \\
10.29-190.47\end{array}$ & $\begin{array}{c}62.7 \pm 456.9 \\
10.12-187.25\end{array}$ & $0.366^{*}$ \\
\hline
\end{tabular}

*comparision two group at the baseline $(p>0,05)$. $p$-value from Man Whitney test and $\mathrm{X}^{2}$ test

\section{Volume 4 Issue 12, December 2015}




\section{International Journal of Science and Research (IJSR) \\ ISSN (Online): 2319-7064}

Index Copernicus Value (2013): 6.14 | Impact Factor (2014): 5.611

Table 2: The mean level of SOD, CAT, GPx, MDA Pre and Post and Delta in the Control Group and the Treatment

Group.

\begin{tabular}{|c|r|c|r|r|}
\hline \multirow{2}{*}{ Variables } & \multicolumn{2}{|c|}{ Treatment $(n: 38)$} & \multicolumn{2}{c|}{ Control $(n: 38)$} \\
\cline { 2 - 5 } & \multicolumn{1}{|c|}{ pre } & post & \multicolumn{1}{c|}{ pre } & \multicolumn{1}{c|}{ Post } \\
\hline SOD $(\mathrm{U} / \mathrm{mL})$ & $261 \pm 36,9$ & $337 \pm 52.6$ & $269 \pm 34,4$ & $267 \pm 35.2$ \\
\hline CAT $(\mathrm{U} / \mathrm{mL})$ & $1.8 \pm 0.08$ & $2.0 \pm 0.07$ & $1,9 \pm 0,08$ & $1.9 \pm 0.4$ \\
\hline GPx $(\mathrm{U} / \mathrm{mL})$ & $69.5 \pm 13.9$ & $79.9 \pm 12.3$ & $70.4 \pm 14.9$ & $68.8 \pm 147$ \\
\hline MDA $(\mathrm{nmol} / \mathrm{mL})$ & $4.5 \pm 0.5$ & $3.6 \pm 0.4$ & $4.4 \pm 0.5$ & $4.5 \pm 0.5$ \\
\hline
\end{tabular}

Table 3: The Analysis Result of the Mean Difference After Treatment on the Control and Treatment Group in the level of SOD,CAT,GPx and MDA

\begin{tabular}{|c|c|c|c|}
\hline \multirow{2}{*}{ Variables } & \multicolumn{2}{|c|}{ Mean \pm SD } & \multirow{2}{*}{-value } \\
\cline { 2 - 3 } & $\begin{array}{c}\text { Treatment } \\
(n: 38)\end{array}$ & $\begin{array}{c}\text { Control } \\
(n: 38)\end{array}$ & \\
\hline SOD $(\mathrm{U} / \mathrm{mL})$ & $337 \pm 52.5$ & $267 \pm 35.2$ & $0.000^{*}$ \\
\hline $\mathrm{CAT}(\mathrm{U} / \mathrm{mL})$ & $2.0 \pm 0.5$ & $1.9 \pm 0.4$ & $0.109^{* *}$ \\
\hline $\mathrm{GPx}(\mathrm{U} / \mathrm{mL})$ & $79.9 \pm 12.3$ & $68.8 \pm 14.7$ & $0.002^{*}$ \\
\hline $\mathrm{MDA}(\mathrm{nmol} / \mathrm{mL})$ & $3.6 \pm 0.4$ & $4.5 \pm 0.5$ & $0.000^{*}$ \\
\hline
\end{tabular}

*Significant $(\mathrm{p}$-value $<0,05)$

**not significant ( $\mathrm{p}$-value $>0,05$ ). $\mathrm{p}$-value from Man Whitney test

Table 4: The Summary of the Analysis Result of the Mean Change Difference (delta) In the Control and Treatment Group

\begin{tabular}{|c|c|c|c|c|}
\hline \multirow{2}{*}{ Variabel } & \multicolumn{2}{|c|}{ Mean $\pm S D$} & \multirow{2}{*}{$p$-value } & \multirow{2}{*}{$\begin{array}{c}\text { Mean } \\
\text { Difference } \\
K-P\end{array}$} \\
\hline & $\begin{array}{c}\text { Treament } \\
(n: 38)\end{array}$ & $\begin{array}{c}\text { Control } \\
(n: 38)\end{array}$ & & \\
\hline SOD $(\mathrm{U} / \mathrm{mL})$ & $75.4 \pm 27.4$ & $-1.7 \pm 8.2$ & $0.000^{*}$ & 73.7 \\
\hline CAT $(\mathrm{U} / \mathrm{mL})$ & $0.23 \pm 0.28$ & $-0.04 \pm 0.25$ & $0.000 *$ & 0.19 \\
\hline GPx $(\mathrm{U} / \mathrm{mL})$ & $10.4 \pm 11.8$ & $-1.55 \pm 3.8$ & $0.000 *$ & 8.85 \\
\hline $\mathrm{MDA}(\mathrm{nmol} / \mathrm{mL})$ & $-0.95 \pm 0.1$ & $0.26 \pm 0.5$ & $0.000^{*}$ & -0.69 \\
\hline
\end{tabular}

*signicant ( $\mathrm{p}$-value $<0,05)$. $\mathrm{p}$-value from Man Whitney test

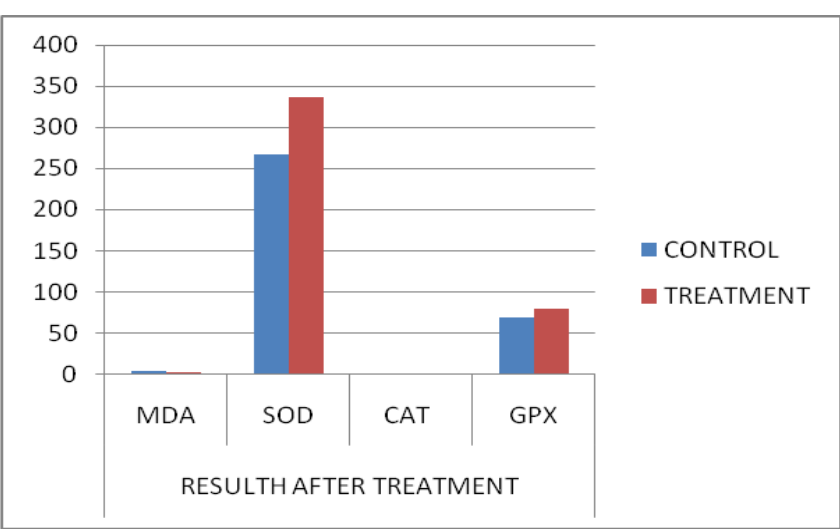

Chart 1: The Mean Level Difference of MDA, SOD, CAT and GPX After Treatment on the Control and Treatment Group ( $\mathrm{n}=38$ per group)

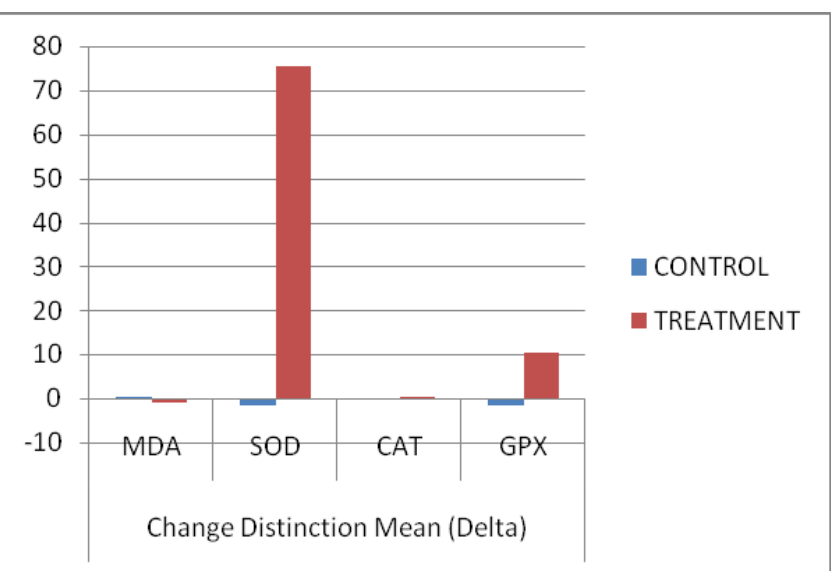

Chart 2: Delta Level of MDA, SOD, CAT and GPX Control and Treatment Group ( $\mathrm{n}=38$ per group)

\section{Discussion}

High blood mercury level indicate that the level of free radicals in the body is high. The main target of free radicals is a protein, unsaturated fatty acids, as well as DNA elements including carbohydrates. Out of the three molecule targets, unsaturated fatty acid is a compound that is the most susceptible to free radical attack. High level of free radicals in the body can be shown by the low activity of antioxidant enzymes and high level of malondialdehyde (MDA) in blood plasma. $\stackrel{\mathbf{2}}{ }$

The Spearman's test showed that there was a significant correlation between mercury levels in the blood and MDA levels $(p=0.002)$ in which the correlation is positive, it means that the higher the level of mercury in the blood, the higher the level of MDA, as an indication for the occurrence of lipid peroxidation, There is a correlation between blood mercury levels with antioxidant SOD $(p=0.029)$, the levels of CAT $(p=0005)$, and the levels of GPx $(p=0.008)$ in which the correlation is negative, it means that the higher blood mercury level, the lower the level of SOD, CAT and GPx.The results are consistent with the research conducted by Al-azzawie et al in which the research shows that there is significant relationship between the level of mercury in the blood and the level of MDA, SOD and GPx of workers exposed to mercury.

Mercury is a free radical. These compounds have a strong affinity for thiol or sulfhydryl. $\underline{\mathbf{2 2}}, \underline{\mathbf{2 3}}$ Mercury binds the thiol groups found in antioxidant proteins so the activity decreases. This condition blocks the activity of antioxidant enzymes resulting in the depletion of glutathione and the rise of $\mathrm{H}_{2} \mathrm{O}_{2}{ }^{22}$ If Hydrogen peroxide reacts with transition metal (transitional metals) such as $\mathrm{Fe}++$ and $\mathrm{Cu}+$ in the reaction of Fenton, it will generate hydroxyl radical $(\bullet \mathrm{OH})$, which is the most dangerous because of their reactivity is very high. $\underline{24}$

Mercury in the body is also able to inhibit methioneine synthase (SM) in the methionine cycle, thereby disturbing GSH synthesis resulting in the drop of GSH level. $\underline{\mathbf{2 5}}$ in order to prevent the harmful effects of ROS, cells need a lot of self-defense mechanism that is endogenous antioxidant enzymatic and non-enzymatic. Glutathione (GSH), ascorbate, uric acid is non-enzymatic defense mechanism, 


\section{International Journal of Science and Research (IJSR) \\ ISSN (Online): 2319-7064}

Index Copernicus Value (2013): 6.14 | Impact Factor (2014): 5.611

while superoxide dismutase (SOD), catalase (CAT) and glutathione peroxidase (GPx) belong to enzimatic mechanism. 2 Lack of one antioxidant component leads to a decrease in overall antioxidant status and results in weakening protection against ROS attack. $\underline{\mathbf{2 6}}, \underline{\mathbf{2 7}}$

Coconut water used in this study was tender coconut water from coconut cultivar group, vareitas viridis (green coconut), 5-7 months, total sugar contents increases from 5 months to reach the maximum at 7 months. Subsequently, total sugar rapidly decreases until fully ripe at the age of 12 months. $\underline{\mathbf{2 8}} \underline{\underline{31}}$ Tender coconut water contains antioxidants such as vitamin $\mathrm{C}$, vitamin B1, vitamin B6, amino acids such as methionine, L-Arginine, selenium, cytokinins and minerals that are beneficial to protect body cells againts free radical attack and prevent against the effects resulting from exposure to mercury. $\underline{\mathbf{1 6}}, \underline{29}-\underline{31}$

In this study, tender coconut water has been proven to increase antioxidant status of SOD, CAT and GPx blood, the mean levels of SOD, CAT and GPx blood are proven to increase after tender coconut water is given. These results support the research by Bhagya et al $\underline{16}$ stating that giving tender coconut water can increase the levels of antioxidant enzymes of SOD, CAT and GPx in tissues of mice fed highfructose. Loki and Rajamohan $\underline{18}$ support the finding by stating that tender coconut water can increase the levels of $\mathrm{SOD}, \mathrm{CAT}$ and GPx in rats induced with $\mathrm{CCl}_{4}$. Anurag and Rajamohan $\underline{22}$ state in their research that tender coconut water can increase the activity of antioxidant enzymes (TAC) in rats induced by isoproterenol. The mean levels of CAT enzyme after treatment in the treatment group had an increase compared to the control group, however the increase was not statistically significant $(p>0.05)$. It is assumed that capacity of CAT enzyme reduction is high at the atmosphere $\mathrm{H}_{2} \mathrm{O}_{2}$ in high concentration, while in the lower concentration, the capacity also drops, this is because the CAT enzyme reaction requires two molecules of $\mathrm{H}_{2} \mathrm{O}_{2}$ in the reduction process, so it is rarely found at low substrate concentration. ${ }^{33}$ CAT and GPx enzymes have the same properties in catalyzing $\mathrm{H}_{2} \mathrm{O}_{2}$, at low or normal $\mathrm{H}_{2} \mathrm{O}_{2}$ concentration GPx has a more dominant role for catalyzing $\mathrm{H}_{2} \mathrm{O}_{2}$ than that of CAT. High glucose level is assumed to inhibit the activity of the enzyme CAT, a study of the effect of various levels of glucose to the enzyme CAT, found that there is a drop of CAT enzyme activity on high glucose levels. $\stackrel{33}{ }$ Examination of glucose level to the subjects in this study was not conducted so that the researchers did not have data on which subject had normal, low or high glucose level. The absence of a significant increase in CAT levels in the treatment group compared to that of control group was likely to occur that the subject of the treatment group has high blood glucose levels.

Component of amino acid such as methionine found in tender coconut water is a source of sulfhydryl for cysteine. Methionine acts as a precursor to formation of cysteine which is the main compound in the synthesis of glutathione (GSH). Methionine will be synthesized into Sadenosilmetionin (SAM) aided by the enzyme catalysat of methionine adenosiltransfrease. Then, S-adenosilmetionin (SAM) will be converted into S-adenosilhomosistein (SAH), SAH will be converted into homocysteine with the help of adenosilhomosisteinase enzyme and by methionine synthase (MS) homocysteine can be reconverted into methionine. In cysteine synthesis, homocysteine will be converted into cystathionne with the help of the enzyme of cystathionine $\beta$ synthase (CBS) and vitamin B6 and then converted into cysteine with the help of sistationin lyase enzyme and vitamin B6, eventually cysteine will be synthesized into glutathione (GSH) . 또, $\underline{\mathbf{3 4}}, \underline{\mathbf{3 5}} \mathrm{GSH}$ is a substrate for the antioxidant glutathione peroxidase (GPx) to decompose hydrogen peroxide, if glutathione synthesis gets disturbed, it will cause a drop in GSH and there will be a dump of hydrogen peroxide and ultimately there will be a rise hydroxyl radicals which is more harmful to the human body. GSH also serves as a substrate in the reaction of vitamin $\mathrm{C}$ radical regeneration into vitamin $\mathrm{C}$, so that if the drop of GSH occurs, it will interfere the reaction and will lead to lipid peroxidation. Methionine works in synergy with vitamin B6. Vitamin B6 acts as a cofactor of the enzyme of cystathionine $\beta$ synthase and lyase sistationin on the synthesis process of cysteine and GSH.

Tender coconut water can be used as a source of methionine

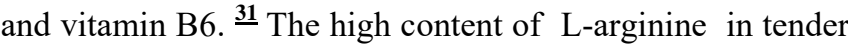
coconut water can be used to reduce the free radical generation, increase antioxidant activity and inhibit the process of lipid peroxidation. $\underline{\mathbf{1 6}}, \underline{\mathbf{1 7}}, \underline{\mathbf{3 2}}$ L-arginine plays an important role in mercury detoxification and serves potentially as a preventive and therapeutic strategies against occcupational or environmental exposure to mercury. $\frac{\mathbf{3 6}}{}$ L-arginine is a source of nitrid oxide (NO). NO can inhibit xantine Oxidase (XO), increase levels of SOD, total thiol (T$\mathrm{SH}$ ), vitamin $\mathrm{C}$, total antioxidant (TAC) $\stackrel{37-39}{-3}$ If the $\mathrm{XO}$ activity decreases, the amount of superoxide will also decrease so that the levels of SOD increase because the need of SOD to decompose superoxide into hydrogen peroxide is also less. Fang et al. reported that superoxide can also be formed due to the reduction of $\mathrm{O}_{2}$ by NO synthase when a shortage of arginine and tetrahidribiopterin $\left(\mathrm{BH}_{4}\right)$ occurs, so that L-arginine can be used as an alternative to reduce production of superoksida. $\underline{\mathbf{4 0}}$

The increase of Thiol levels after giving of L-arginine can increase the conversion of ascorbic acid radicals into ascorbat acid. $\underline{38}$ Treatment by L-arginine can increase GPx activity in rats exposed with $\mathrm{Pb}$. $\stackrel{41}{1}$ The high content of vitamin $\mathrm{C}$ in tender coconut water makes coconut water effective to increase the level of antioxidants as vitamin $\mathrm{C}$ can reduce superoxide radicals, hydrogen peroxide and reactive oxygen derived from activated neutrophils and monocytes. The work of ascorbic acid as an antioxidant indirectly regenerates membrane antioxidant bonding, such as $\alpha$-tocopherol, by raising peroxyl radicals and singlet oxygen. Vitamin $\mathrm{C}$ works synergistically with vitamin $\mathrm{E}$. Vitamin $\mathrm{E}$ oxidized by free radicals can react with vitamin $\mathrm{C}$, after obtaining the hydrogen ions of vitamin $\mathrm{C}$ and then it will convert into tokoferol. $\stackrel{2}{=}$ Tender coconut water contains selenium, GPx activity is strongly influenced by the presence of selenium, selenium deficiency in the body can decrease the activity of GPx up to $90 .{ }^{\mathbf{4 2}}$ Mercury has strong affinity to bind selenium, $\underline{\mathbf{2 2}}$ and both are antagonis. $\underline{43}$ Giving tender coconut water for workers exposed to mercury can be used as a source of selenium to increase the activity of GPx.

\section{Volume 4 Issue 12, December 2015}




\section{International Journal of Science and Research (IJSR) \\ ISSN (Online): 2319-7064}

Index Copernicus Value (2013): 6.14 | Impact Factor (2014): 5.611

High nutrient content in tender coconut water can be used as a source of minerals which is essential to the body, one of them is as a natural cofactor antioxidants SOD contained in the body. Mineral deficiency of $\mathrm{Cu}, \mathrm{Zn}$ and $\mathrm{Mn}$ can lower the activity of $\mathrm{Cu}-\mathrm{Zn}$ SOD and Mn-Mn-SOD. $\stackrel{40}{-} \mathrm{Mn}-\mathrm{SOD}$ serves as a catalyst for the dismutase reaction of the anion superoxide into hydrogen peroxide $\left(\mathrm{H}_{2} \mathrm{O}_{2}\right)$ and oxygen $\left(\mathrm{O}_{2}\right)$ in the mitochondria, while $\mathrm{Cu}-\mathrm{Zn}$ SOD serves as a catalyst for the dismutase reaction of the anion superoxide into hydrogen peroxide $\left(\mathrm{H}_{2} \mathrm{O}_{2}\right)$ and oxygen $\left(\mathrm{O}_{2}\right)$ in the cytosol. In this $\mathrm{Cu}-\mathrm{Zn} \mathrm{SOD}, \mathrm{Cu}$ mineral is necessary for the proper functioning of the enzyme catalytic, while $\mathrm{Zn}$ is important for the structural function. Minerals $\mathrm{Cu}, \mathrm{Zn}$ and $\mathrm{Mn}$ work in synergy. $\stackrel{2}{ }$

\section{Conclusions}

The present study shows that consumption $450 \mathrm{~mL} /$ day of tender coconut water for 30 day increases antioxidant enzymatic SOD, CAT, GPx and decreases lipid peroxidation in mercury exposure workers.

\section{Novelty}

The benefit of tender coconut water to prevent mercury contamination therefore it can help health care service in preventing morbidity and mortality, especially for workers exposed to mercury. Since this study was conducted in humans, the results were in line with the actual situation.

\section{Acknowledgements}

This research was supported by the Government of the Republic of Indonesia through the Directorate General of Higher Education (BPPS) and Sultan Agung Islamic University (UNISSULA) Semarang. The researchers would like to thank the traditional gold miners (respondents) for their contribution..

\section{Conflict of Interest}

The Authors declared no conflict of interest

\section{References}

[1] Afriza D. The Effect of Mercury Vapor and the Role of Green Tea Extract on Brain cells. Journal of Dentistry Indonesia. 2013;20(2):39-45.

[2] Winarsi H. Antioksidan Alami \& Radikal Bebas. 3 ed. Yogyakarta: Kanisius; 2007

[3] Hyman M. The Impact of Mercury on Human health and The Environment. Alternative Therapies 2004; 10:70-5.

[4] UNEP. Global Mercury Assessment : Sources, Emissions, Releases and Environmental Transport. 2013. p. 24-7.

[5] KESDM. Rencana Aksi Nasional penghapusan Penggunanan Merkuri pada Pengolahan Emas 20142018. 2013.

[6] Patrick L. Mercury Toxicty and Antioxidants : Part I : Role of Glutathione and Alpha-Lipoic acid in the
Treatment of Mercury Toxicity Alternative Medicine Review. 2002;7:456-71.

[7] NRC. Effect of Metyhmercury Board on Environmental Studies and Toxicology Commision on Life Sciences. Toxicological Effect of Metyhmercury. Washington DC: National Academy Press; 2000.

[8] Al-azzawie HF, Umran A, Hyader NH. Oxidative Stress, Antioxidant Status and DNA Damage in a Mercury Exposure Workers. British Journal of Pharmacology and Toxicology. 2013;4(3):80-8.

[9] Houston MC. The role of mercury and cadmium heavy metals in vascular disease, hypertension, coronary heart disease and myocardial infarction. Alternative Therapies in Health and Medicine. 2007;13:128-33.

[10] Sharma MK, Kumar M, Kumar A. Ocimum sanctum aqueous leaf extract provides protection against mercury induced toxicity in Swis albino mice. Indian Journal of Experimental Biology 2002;40:1079-82.

[11] Effect Neurologist Mercury Exposure [database on the Internet]. 2005 [cited Juni 2013].

[12]Jan AT, Ali A, Haq QMR. Glutation as an Antioxodant in Inorganic Mercury Induced Nephrotoxicity. Review Article. 2011;57:72-7.

[13] Devasagayam T, Tilak J, Boloor K, Sane KS, Ghaskadbi SS, Lele R. Free Radicals and Antioxidants in Human Health: Current Status and Future Prospects. JAPI. 2004;52.

[14] Astuti S. Isoflavon Kedelai dan Potensinya sebagai Penangkap Radikal Bebas. Jurnal Teknologi Industri dan Hasil Pertanian 2008;13:126-36.

[15] Kemendustrian RI. Roadmap Industri Pengolahan Kelapa Direktorat Jenderal Industri Agro. In: Perindustrian K, editor. Jakarta2010.

[16] Bhagya D, Prema L, Rajamohan T. Therapeutik Effects of Tender Coconut water on Oxidative Stress in fructosa fed Insulin Resistant Hypertensive Rats. Asian Pasific Journal of Tropical Medicine. 2012:270-6.

[17] Anurag P, Rajamohan T. Cardioprotective effect of tender coconut water in experimental myocardial infarction. . Plants Foods Hum Nutr. 2003;58:1-12.

[18]Loki AL, Rajamohan T. Hepatoprotective and Antioxidant Effect of Tender Coconut Water on Carbon tetrachloride Induced Liver Injury in Rats. Indian Journal of Biochemistry \& Biophysics. 2003;40:354-7.

[19] Campbell DT, Stanley JC. Experimental and Quasi Experimental Design for Research. Rand McNally College Publising Company: Chicago; 1966. p. 13-24.

[20]Dahlan MS. Besar Sampel dan Cara Pengambilan Sampel dalam Penelitian Kedokteran dan Kesehatan. Jakarta: Salemba Medika; 2010.

[21] Machin D, Campbell MJ, Tan SB, Tan SH. Sample Size Tables for Clinical Studies. 3 ed. USA: WileyBlackweell; 2009.

[22] SamZiff. The Toxic Time Bomb Can The Mercury in Your Dental Fillings Poison You. 4 ed. USA: Aurora Press; 2002.

[23] Rooney JPK. The Role of Thiol, Dithiol, Nutrional Factors and Interacting Ligans in the Toxicology of Mercury. Toxicology. 2007;234:145-56.

[24] Suryohudoyo P. Kapita Selekta Ilmu Kedokteran Molekuler. 2 ed. Jakarta: Sagung Seto; 2007. p. 31-47.

[25] Baker SM. Who Ignores Individuality Fails the Patient. A Clinician's Journal New York. 2007:88-95. 


\section{International Journal of Science and Research (IJSR) \\ ISSN (Online): 2319-7064}

Index Copernicus Value (2013): 6.14 | Impact Factor (2014): 5.611

[26] Maslachah L, Sugihartuti R, Kurniasanti. R. Hambatan produksi Reactive Oxygen Spesies Radikal Superoksida $(\mathrm{O} 2 \cdot-)$ oleh antiokidan Vitamin E ( $\alpha$-tocoferol) pada tikus Putih (Rattus norvegicus) yang menerima Stressor Renjatan Listrik. Media Kedokteran Hewan. Media Kedokteran Hewan. 2008;24(1):21-6.

[27] Halliwel B. Oxygen Spesies Radikal in Living system. Source biochemistry and role in human decease. Am J 1991;91:110-5.

[28] Priya SR, Ramaswamy L. Tender Coconut WaterNatures Elixir to Mankid. International Journal of Recent Scientific Research. 2014;5(8):1485-90.

[29]Fife B. Coconut Water for Health and Healing. USA: Piccadily Books, Ltd; 2008.

[30] Alexia P, Dornier M, Diop N, Pain J-P. Coconut Water Uses, Composition and properties : a review. Fruits. 2011;67:87-107.

[31] Yong JWH, Ge L, Ng YF, Tan SN. The Chemical Composition and Biological Properties of Coconut (Cocos nucifera L) water. Molecules. 2009;14:5144-64.

[32] Anurag P, Rajamohan T. Beneficial effect of tender coconut water against isoproterenol induced toxicity on heart mitochondrial activities in rats. Indian Journal of Biochemistry and Biophysics 2003;40:278-80.

[33] Tukan MF. Kadar Antioksidan Enzimatik Katalase pada Abortus Inkomplit Lebih Rendah Dibandingkan dengan Kehamilan Normal Trimester Pertama [Thesis]. Denpasar: UDAYANA; 2014.

[34] James SJ. . Metabolic biomarker of increased oxidative stress and impaired methylation capacity in children with autism. Am j Clin Nutr 2004;80(6):1611-7.

[35] Atmaca G. Antioxodant Effect of Sulfur Containing Amino Acid. Yonsei Medical Journal. 2004;45:776-88.

[36] Bracci M, Tomasetti M, Malavolta M, Bonacucina V, Mocchegiani E, Santarella L. L-arginine Reduces Mercury Accumulation in Tymus of Mercury-exposed Mice : Role of Nitric Axide Synthase Activity and Metallothionins. Industrial Health. 2008;46:567-74.

[37] Tripathi P, M.Chandra, Misra MK. Oral Administration of 1-Arginine in Patients with Angina or following Myocardinal Infarction may be Protective by Increasing Plasma Superoxida Dismutase and Total Thiol with Reduction in Serum Cholesterol and Xanthine oxidase. Oxid Med Cell Longev. 2009;2(4):231-7.

[38] Tripathi P, Misra MK. Therapeutic Role of L-Arginine on Free Radical Scavenging System in Ischemic Heart Diseases. Indian Journal of Biochemistry \& Biophysics. 2009;46:498-502.

[39] Fazelian S, Hoseini M, Namazi N, Heshmati J, Kish MS, Mirfatahi M, et al. Effects of L-Arginine Supplementation on Antioxidant Status and Body Composition in Obese Patients with Pre-diabetes : A Randomized Controlled Clinical Trial. Adv Pharm Bull. 2014;4(1):449-54.

[40] Fang YZ, Yang S, Guoyao. Free Radicals, Antioxidant, and Nutrien. Nutrition. 2002;18:872-9.

[41] Tkachenko H, Kurhalyuk N. Role of L-Arginine Against lead Toxicity in Liver of Rats with Different Resistance to Hypoxia. Pol J Environ Stud. 2011;20(5):1319-25.

[42] Sivanandham V. free Radicals in Health and Diseases A Mini Review. Pharmacologyonline 2011;1:1062-77.
[43] Yang DY, Chen YW, Gunn JM, Belzile N. Selenium and Mercury in Organism : Interactions and Mechanisms. Environ Rev. 2008;16:71-92. 